four rural and urban communities. PLoS ONE 2012;7: e32638.

8. Chisholm D, Baltussen R, Evans DB, et al. What are the priorities for prevention and control of non-communicable diseases and injuries in sub-Saharan Africa and South East Asia? BMJ 2012;344:e586.

\section{SIMULTANEOUS PML-IRIS AFTER DISCONTINUATION OF NATALIZUMAB IN A PATIENT WITH MS}

Stella Marousi, Maria Travasarou, Clementine E. Karageorgiou, Athens, Greece: Gheuens et al. ${ }^{1}$ presented a case of progressive multifocal leukoencephalopathy-immune reconstitution inflammatory syndrome (PML-IRIS) 2 months after natalizumab discontinuation. Their patient had an active history of ethanol abuse, which can be considered a 'functional' equivalent to immunosuppression. Interestingly, prior use of immunosuppressants has been included in the recently developed risk-stratification algorithm for PML. ${ }^{2}$ This case underscores the need for clinicians to adopt a wider concept of immunosuppression, rather than restricting it solely to the use of pharmacologic agents. We and others published 3 cases of definitive severe multiple sclerosis (MS) rebound about 2 months following natalizumab discontinuation, ${ }^{3-5}$ and further implied that younger patients are more prone to such relapses. ${ }^{5}$ However, Gheuens et al. concluded that new enhancing MRI lesions after natalizumab withdrawal may also be the manifestation of PML-IRIS. ${ }^{1}$ As experience from patients discontinuing natalizumab and switching to other therapies mounts, a high degree of clinical vigilance for both incidences (i.e., MS rebound and PML) should follow the immediate post-natalizumab period. However, until official guidelines are issued, it is unclear exactly how patients should be treated in the interval between natalizumab and the next therapeutic choice.

Author response: Sarah Gheuens, Igor J. Koralnik, Boston: We thank Marousi et al. for their comments on our article. We agree that PML may also occur in the setting of occult or minimal immunosuppression, as seen in 5 cases at our center and in 33 previously reported patients. ${ }^{6}$ As they mention, clinicians should be aware that either PML-IRIS or a relapse of MS may occur after discontinuation of natalizumab.

(C) 2012 American Academy of Neurology

1. Gheuens S, Smith DR, Wang X, Alsop DC, Lenkinski RE, Koralnik IJ. Simultaneous PML-IRIS after discontinuation of natalizumab in a patient with MS. Neurology 2012;78: 1390-1393.

2. Bloomgren G, Richman S, Hotermans C, et al. Risk of natalizumab-associated progressive multifocal leukoencephalopathy. N Engl J Med 2012;366:1870-1880.

3. Lenhard T, Biller A, Mueller W, Metz I, Schonberger J, Wildemann B. Immune reconstitution inflammatory syndrome after withdrawal of natalizumab? Neurology 2010;75:831-833.

4. Hellwig K, Gold R. Immune reconstitution inflammatory syndrome after withdrawal of natalizumab? Neurology 2011;76: 1362-1363; author reply 1363.

5. Marousi S, Giannouli E, Karkanis I, Tagaris GA, Karageorgiou CE. Immune reconstitution inflammatory syndrome after withdrawal of natalizumab? Neurology 2011;76:1362-1363; author reply 1363.

6. Gheuens S, Pierone G, Peeters P, Koralnik IJ. Progressive multifocal leukoencephalopathy in individuals with minimal or occult immunosuppression. J Neurol Neurosurg Psychiatry 2010;81:247-254. 


\section{Neurology}

Simultaneous Pml-Iris After Discontinuation of Natalizumab in A Patient With MS

Stella Marousi, Sarah Gheuens, Maria Travasarou, et al.

Neurology 2012;79;2160

DOI 10.1212/01.wnl.0000423208.11698.16

This information is current as of November 19, 2012

Updated Information \&

Services

References

Citations

Permissions \& Licensing

Reprints including high resolution figures, can be found at: http://n.neurology.org/content/79/21/2160.full

This article cites 6 articles, 5 of which you can access for free at: http://n.neurology.org/content/79/21/2160.full\#ref-list-1

This article has been cited by 1 HighWire-hosted articles: http://n.neurology.org/content/79/21/2160.full\#\#otherarticles

Information about reproducing this article in parts (figures,tables) or in its entirety can be found online at:

http://www.neurology.org/about/about_the_journal\#permissions

Information about ordering reprints can be found online:

http://n.neurology.org/subscribers/advertise

Neurology ${ }^{\circledR}$ is the official journal of the American Academy of Neurology. Published continuously since 1951, it is now a weekly with 48 issues per year. Copyright @ 2012 American Academy of Neurology. All rights reserved. Print ISSN: 0028-3878. Online ISSN: 1526-632X.

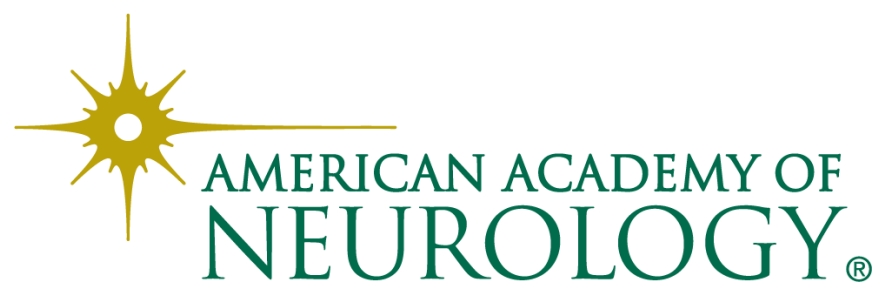

